MICHAŁ J. CZARNECKI

Wydział Humanistyczny UMK

\title{
Lewiatan - ten król wszystkich dzieci pychy. Hobbes w interpretacji Erica Voegelina
}

„Krocząc swoją drogą, zaczynają nienawidzić prawdy z powodu owej rzeczy, którą jako rzekomą prawdę kochają"

S W. A U G US T Y N *

W

połowie ubiegłego stulecia Michael Oakeshott pisząc swoją słynną przedmowę do Lewiatana Thomasa Hobbesa, stwierdził, że dzieło to „jest największym, być może jedynym arcydziełem filozofii politycznej napisanym w języku angielskim. Historia naszej cywilizacji dostarczyła zaledwie paru dzieł o podobnym zakresie i znaczeniu, które można by traktować na równi z Lewiatanem". . Bez wątpienia w trakcie dwudziestego stulecia dzieło Hobbesa doczekało się szerokiej, odpowiadającej tej opinii recepcji. Dorobek tego pisarza interpretowali wybitni reprezentanci dwudziestowiecznej filozofii polityki: Leo Strauss, Carl Schmitt oraz wspomniany już Michael Oakeshott, którzy wydali poświęcone Hobbesowi książki ${ }^{2}$, stanowiące bez wątpie-

Św. Augustyn, Wyznania, ks. X, 23, przeł. Z. Kubiak, Kraków 2008, s. 305-306.

J. C. A. Gaskin, Wstęp [w:] T. Hobbes, Lewiatan, przeł. Cz. Znamierowski, Warszawa 2005, s. 61 .

L. Strauss, The Political Philosophy of Hobbes: It's Basis and Genesis, Oxford 1936; C. Schmitt, Lewiatan $w$ teorii państwa Thomasa Hobbesa: sens i niepowodzenie politycznego symbolu, przeł. M. Falkowski, Warszawa 2008 [1936]; M. Oakeshott, Hobbes on Civil Association, Oxford 1975; tenże, Leo Strauss o Hobbesie, przeł. M. Polakowski, „Dialogi Polityczne” 2009, nr 12, s. 85-98. 
nia istotny głos w dyskusji nad spuścizną tego myśliciela. By oddać obraz szerokiego spektrum zainteresowania Hobbesem, należy wspomnieć także poza licznymi publikacjami o charakterze historyczno-biograficznym, stricte filozoficznym czy filologicznym - o innych bardziej współczesnych interpretacjach w ramach filozoficzno-politycznej refleksji nad polityką ${ }^{3}$. Mam tu na myśli inspirowaną marksizmem koncepcję „zaborczego indywidualizmu” Crawforda B. Macphersona ${ }^{4}$, liberalny kontraktualizm Davida Gauthiera ${ }^{5}$, badania prowadzone przez współczesnego przedstawiciela karlistowskiej filozofii politycznej Miguela Ayuso Torresa ${ }^{6}$ czy prace Quentina Skinnera ${ }^{7}$, zaliczanego do grupy historyków idei zwanych powszechnie „szkołą z Cambridge". Książki autorstwa wyżej wspomnianych autorów należą do kluczowych, choć nieraz silnie polemicznych, głosów w dyskusji nad dorobkiem autora Lewiatana.

W dwudziestowiecznej refleksji nad polityką spotykamy także autorów, którzy nie napisali wprawdzie żadnej książki na temat Hobbesa, nie zapisując się tym samym w historii jako badacze pism „mędrca z Malmesbury”, tym niemniej - jak to jest w wypadku filozofii władzy i suwerenności Bertranda de Jouvenela ${ }^{8}$ czy analizującego w latach czterdziestych nazizm Franza Leopolda Neumanna ${ }^{9}$ - stworzona przez Hobbesa teoria i symbolika należy do niezwykle istotnych punktów odniesienia w ich twórczości. Niewątpliwie do tej grupy badaczy zaliczyć można także innego klasyka dwudziestowiecznej filozofii polityki, Erica Voegelina. Ów uczonybadacz, znany choćby z szeroko dyskutowanej tezy o gnostyckim charakterze nowożytności, uważał Hobbesa za myśliciela o wielkim znaczeniu dla ukształto-

W przypadku tego ostatniego należy także wskazać na niezwykle istotną przedmowę do Lewiatana z 1946 roku, z której pochodzi powyższy cytat.

Zob. przegląd głównych interpretacji Hobbesa: D. D. Raphael, Hobbes: Morals and Polítics, London 1977, s. 73-100.

C. B. Macpherson, The Political Theory of Possessive Individualism: Hobbes to Locke, Oxford 1962; tenże, Modele spoleczeństwa, przeł. K. Marulewska, „Dialogi Polityczne” 2009, nr 12, s. 179196.

D. Gauthier, The Logic of 'Leviathan': the Moral and political Theory of Thomas Hobbes, Oxford 1969. Nurt ten rozwijał Gregory S. Kavka: G. Kavka, Hobbesian Moral and Political Theory, Princeton 1986.

6 M. Ayuso Torres, ¿Después del Leviathan? Sobre el Estado y su signo?, Madrid 1996; tenże, Po Lewiatanie? O państwie i jego znaku (fragmenty), przeł. B. Różycki, „Dialogi Polityczne” 2009, nr 12, s. 151-168.

Q. Skinner, Reason and Rhetoric in the Philosophy of Hobbes, Cambridge 1996; tenże, Visions of Politics Volume 3: Hobbes and Civil Science, Cambridge 2002; tenże, Hobbes and Republican Liberty, Cambridge 2008; tenże, O zmienności Hobbesowskiego ujęcia wiedzy społecznej, przeł. J. Grygieńć, „Dialogi Polityczne” 2009, nr 12, s. 29-50.

B. de Jouvenel, De la souveraineté: a la recherche du bien politique, Paris 1955.

9 F. L. Neumann, Behemoth: The Structure and Practice of National Socialism 1933-1944, Harper 1944. 
wania się tej epoki, i choć nie poświęcił mu osobnej pracy ${ }^{10}$, jego dorobek zawiera wiele fragmentów, na podstawie których można podjąć próbę zrekonstruowania jego stosunku do autora Lewiatana.

Zanim przejdziemy do problemu Voegelinowskiej interpretacji Hobbesa, wydaje się koniecznym zatrzymanie się na chwilę przy kwestii samej obecności tego tematu w pismach Voegelina. Jest to zagadnienie istotne, ponieważ wypowiedzi Voegelina na temat Hobbesa nie mają charakteru zwartego, lecz rozproszony po wielu jego pismach i rozciągnięty na kilka dziesięcioleci jego intelektualnej aktywności.

Okres, w którym Voegelin poświęcał uwagę myśli Hobbesa, przypada na początkowy i środkowy etap jego akademickiej kariery. Rozpoczyna się on w latach trzydziestych, kiedy pracował nad stworzeniem teorii państwa (Staatslehre) w opozycji do koncepcji Rechtslehre, szczególnie w wariancie jego mistrza Hansa Kelsena, która sprowadzała refleksję nad państwem jedynie do namysłu nad systemem norm jako gałęzi prawa konstytucyjnego i szerzej pojętej jurysprudencji1 ${ }^{11}$. Voegelin powziął projekt mający na celu opracowanie systemu składającego się z trzech podstawowych części: teorii władzy, teorii prawa oraz teorii państwa, nad którym pracował w latach 1930-1933 ${ }^{12}$.W części dotyczącej teorii prawa poświęcił więcej miejsca teorii Hobbesa w rozdziale zatytułowanym Fear and Feedom as the Basis Types ${ }^{13}$. Pracy tej Voegelin nigdy jednak nie opublikował za życia i trudno uznać ją, poza walorami biograficzno-antykwarycznymi, za istotne i reprezentatywne świadectwo stosunku do autora Lewiatana.

Chronologicznie kolejną większą wypowiedź Voegelina na temat Hobbesa znajdujemy w niewielkim, lecz ważnym eseju Die politischen Religionen ${ }^{14}$, opublikowanym tuż przed emigracją z Austrii w 1938 roku. Zawiera on cały rozdział poświęcony Lewiatanowi, w którym autor nadaje mu centralne zna-

${ }^{10}$ Można przypuszczać, że nie wynika to z niedoceniania myśli Hobbesa, lecz z przyjętej przez Voegelina metody pisarskiej; większość jego książek ma charakter problemowy, poza tomem Plato and Aristotle, Voegelin nie poświęcił żadnej książki osobnemu myślicielowi. Inaczej jest np. w wypadku L. Straussa, który w swych pracach koncentrował się zwykle na poszczególnych postaciach lub określonych nurtach.

Szeroko omawia ten wątek w swojej najnowszej monografii Barry Cooper (Beginning the Quest: Law and Politics in the Early Work of Eric Voegelin, Columbia-London 2009).

12 Zob. E. Voegelin, The Theory of Governance, [w:] tenże, The Collected Works of Eric Voegelin, Vol. 32: The Theory of Governance and other Miscellaneous Papers 1921-1938, Columbia-London 2003, s. 224-372; tenże, The Theory of Law, [w:] tenże, The Collected Works of Eric Voegelin, Vol. 32: The Theory..., s. 373-413.

13 E. Voegelin, The Theory of Law..., s. 389-401.

${ }^{14}$ Tenże, Die politischen Religionen, Vienna 1938. Opieram się tu na wydaniu amerykańskim: E. Voegelin, The Political Religions, przeł. V. A. Schildhauer, [w:] tenże, The Collected Works of Eric Voegelin, Vol. 5: Modernity without Restraint, Columbia-London 2000, s. 19-73. 
czenie w ukształtowaniu się wewnątrzświatowych religii politycznych. Do tego okresu można zapewne zaliczyć także fragment History of Political Ideas, wielotomowej historii idei politycznych pisanej przez Voegelina w latach 40 . w USA. Dzieło to zostało wydane po śmierci Voegelina w ośmiu tomach dzieł zebranych. Fragment dotyczący Hobbesa znajduje się w siódmym tomie zatytułowanym The New Order and Last Orientation, w rozdziale poświęconym zagadnieniom państwa narodowego ${ }^{15}$. W obu fragmentach znajdujemy już te wątki, które będą także charakterystyczne dla późniejszych pism Voegelina, jak np.: zaznaczanie tego, że ani motyw kontraktualistyczny, ani absolutystyczny nie stanowią prymarnego elementu w filozofii Hobbesa, podkreślanie znaczenia jego pism w dziedzinie problematyki teologiczno-politycznej, wielkie uznanie dla jego psychologicznej przenikliwości.

Kolejne wypowiedzi Voegelina na temat Hobbesa znajdujemy w jego pismach publikowanych $\mathrm{w}$ następnej dekadzie, począwszy od wydanej w 1952 roku Nowej nauki polityki ${ }^{16}$, przez poszczególne drobniejsze pisma ${ }^{17}$, po zbiór esejów Wissenschaft, Politik, und Gnosis ${ }^{18}$ z 1959 roku. Po tym okresie, w pismach Voegelina coraz intensywniej pracującego nad własną filozoficzną teorią świadomości trudno znaleźć już szersze wypowiedzi na temat autora Lewiatana.

Podsumowując ten krótki przegląd, wypada stwierdzić, że zainteresowanie Voegelina Hobbesem rozpoczyna się w latach 30., kończy zaś w latach 50., kiedy autor Nowej nauki polityki, jak się zdaje, ostatecznie wypracował swój stosunek do tego myśliciela. Stąd ostatni z wyróżnionych przeze mnie okresów będzie podstawą analizy interpretacji Hobbesa dokonanej przez Voegelina, zaś wypowiedzi z okresów uprzednich będą służyły jedynie jako tło dla naszych rozważań.

Przemyślenia nad spuścizną Hobbesa w pismach Voegelina pojawiają się w ścisłym powiązaniu z teorią gnozy jako istoty nowożytności. Charakte-

${ }^{15}$ Zob. tenże, The Collected Works of Eric Voegelin, Vol. 25: History of Political Ideas, Vol. VII, The New Order and Last Orientation, Columbia-London 1999, s. 60-71.

Tenże, Nowa nauka polityki, przeł. P. Śpiewak, Warszawa 1992, s. 140-147, 162-170.

Zob. tenże, Gnostische Politik, „Merkur” 1952, nr 4, s. 301-317; tenże, The Oxford Political Philosophers, „The Philosophical Quarterly” 1953, Vol. 3, nr 11, s. 97-114; wystąpienie z 1954 roku na XXV dorocznym kongresie Southern Political Science Association: tenże, What is Political Theory, [w:] tenże, The Collected Works of Eric Voegelin, Vol. 32: The Drama of Humanity and other Miscellaneous Papers 1939-1985, Columbia-London 2004, s. 53-66; niepublikowana recenzja książki Raymonda Polina, Politique et philosophie chez Thomas Hobbes dostępna [w:] tenże, The Collected Works of Eric Voegelin, Vol. 13: Selected Book Reviews, Columbia-London 2001, s. 189-191.

18 E. Voegelin, Wissenschaft, Politik, und Gnosis, Munich 1959. Opieram się tu na wydaniu amerykańskim: tenże, Science, Politics, and Gnosticism, [w:] tenże, The Collected Works of Eric Voegelin, Vol. 5: Modernity without...., s. 243-315. 
ryzuje ją przede wszystkim akcentowanie znaczenia średniowiecznego mnicha Joachima z Fiore i stworzonej przez niego trynitarnej symboliki, która zdaniem Voegelina - wyznacza sposób samointerpretacji współczesnych ruchów politycznych ${ }^{19}$. Jednak $\mathrm{w}$ analizach Voegelina równie istotny $\mathrm{w}$ tym kontekście jest autor Lewiatana i zawarta w jego dziele symbolika, przez którą znajduje swój wyraz zasada radykalnej immanentyzacji współczesnej polityki. Voegelin wskazuje na trzy zasadnicze symbole: nowej psychologii, nowej idei człowieka oraz symbol Lewiatana ${ }^{20}$. W istocie jednak trzy najważniejsze kwestie, jakie uwypukla Voegelin w myśli Hobbesa, można sprowadzić do dwóch kluczowych zagadnień: nowej antropologii oraz teologii politycznej. Analizie tych wątków poświęcimy dalszą cześć niniejszego eseju.

\section{Teologia obywatelska a problem ładu politycznego}

Zdaniem Voegelina wielkim osiągnięciem Hobbesa było podjęcie w nowy i przenikliwy sposób zagadnienia teologii obywatelskiej ${ }^{21}$. Tym samym Voegelin traktuje Hobbesa jako autora o kapitalnym znaczeniu we własnej filozofii historii ${ }^{22}$, której sednem jest historyczny proces zmagania się człowieka z problemem transcendencji ${ }^{23}$. W tym kontekście napisał w Nowej nauce polityki: „Wyłaniają się kontury olbrzymiego cyklu przekraczającego cykle poszczególnych cywilizacji. Szczyt tego cyklu wyznaczają narodziny Chrystusa. Przedchrześcijańskie cywilizacje tworzyłyby jego wstępującą gałąź, z kolei nowożytne cywilizacje gnostyckie - gałąź zstępującą. Rozwinięte cywilizacje przedchrześcijańskie rozwijały się od zwartego doświadczenia do wyróżnienia duszy jako zmysłu transcendencji. Nowożytne cywilizacje odwróciły ten kierunek i w stopniu, w jakim osłabiają owo zróżnicowanie, jego dynamika ma charakter recesywny" ${ }^{24}$.

Nie miejsce tu na rozważanie kwestii filozofii historii Voegelina, warto jednak poczynić kilka uwag ogólnej natury. Przede wszystkim należy zazna-

Zob. tenże, Nowa nauka..., s. 166-167.

Zob. tamże, s. 167-168.

Zob. tamże, s. 145.

Zob. na ten temat: E. Webb, Eric Voegelin: Philosopher of History, Seattle-London 1981, zwłaszcza s. 237-267; G. Hughes, Transcendence and History: the Search for Ultimacy from Ancient Societies to Postmodernity, Columbia 2003; B. Cooper, Eric Voegelin and the Foundations of Modern Political Science, Columbia-London 1999, s. 212-246; J. Day, Voegelin, Schelling and the Philosophy of Historical Existence, Columbia-London 2003, zwłaszcza s. 183-266.

23 Z pism Voegelina doskonałym sumarycznym wprowadzeniem $w$ tę kwestię jest obszerny tekst: The Drama of Humanity, [w:] tenże, The Collected Works of Eric Voegelin, Vol. 33: The Drama of Humanity and other Miscellaneous..., s. 174-242.

24 E. Voegelin, Nowa nauka..., s. 150-151. 
czyć, że - jak zwraca na to uwagę badacz i tłumacz dzieł Voegelina, Gerhard Niemeyer - filozofia historii Voegelina ma zupełnie odmienny charakter niż spekulacje na temat sensu historii, jakie występują w nowożytności począwszy od wariantów oświeceniowych (Johann Gottfried Herder, Anne Turgot, J.-A.-N. de Condorcet, Immanuel Kant), przez koncepcje dziewiętnastosieczne (Charles Fourier, Henri de Saint-Simon, Johann Gottlieb Fichte, G.W.F. Hegel, Karl Marx), aż po ujęcia współczesne Voegelinowi (Oswald Spengler, Arnold Toynbee) ${ }^{25}$. Słynne zdanie otwierające pierwszy tom Order and History, zatytułowany Israel and Revelation - „ład historii wyłania się z historii ładu”, jest pełnym wyrazem takiego nastawienia, które umieszcza absolut poza historią. Wynika z tego również to, iż, jak twierdzi Ryszard Legutko, teoretyk staje przed zadaniem rekonstrukcji historii ładu, „historii nadawania teoretycznego kształtu rozmaitym zbiorowym wysiłkom samointerpretacji społeczeństw poprzez instytucje, religię, obyczaje, prawo czy literaturę" ${ }^{27}$. Stąd, zdaniem Voegelina, „istota historii jest odnajdywana na poziomie doświadczeń, a nie na poziomie idei" ${ }^{28}$. Filozofia historii Voegelina sytuuje się zatem w ufundowanej przez św. Augustyna ${ }^{29}$ tradycji myślenia o dziejach powszechnych. „Voegelin - przekonuje Niemeyer - bada nie sens historii, lecz świadectwa odnoszące się do sensu czasu ukazującego się w historii".

Miejsce Hobbesa w twórczości Voegelina osadzone jest ściśle w kontekście badań nad epoką nowożytną, którą Voegelin opisał za pomocą teorii gnozy. Mówi ona, że nowożytność jest zdeformowaną postacią chrześcijaństwa i ze swej istoty jest cywilizacją radykalnie przeciwstawną cywilizacji śródziemnomorskiej, uosabianej w myśli Voegelina przede wszystkim przez filozofię grecką. Można zatem powiedzieć, że dla Voegelina w analizach nowożytności glebą, z której wyradza się ta epoka, jest w prostej linii średniowiecze, zaś bezpośrednim punktem odniesienia kultura antycznej Grecji.

Zob. G. Niemeyer, Eric Voegelin's Achievement, „Modern Age” 1965, Vol. 29, nr 2, s. 137.

E. Voegelin, Order and History: Israel and Revelation, Baton Rouge 1956, s. ix.

R. Legutko, Eric Voegelin: polityka i transcendencja, „Znak” 1985, nr 9-10, 1985, s. 135. „Historia stanowi pewną formę wyrażania ludzkiego doświadczenia, wyznaczonego poprzez relacje człowieka wobec eschatonu [...] historia jest więc jedynie świadectwem pewnego dramatu, a nie jego autorem; nie mając własnego scenariusza dramatycznego ani własnego immanentnie przypisanego celu nie może ona być narzędziem rozwiązywania podstawowych dylematów kondycji ludzkiej" (tamże, s. 135-136).

E. Voegelin, Nowa nauka..., s. 118. Stąd bierze się odejście Voegelina od pisania historii idei i doktryn politycznych i zwrot ku filozoficznemu badaniu usymbolizowanych, pierwotnych doświadczeń człowieka. Zob. J. Bartyzel, Eryka Voegelina nowa nauka polityki, „Pro Fide, Rege et Lege" 1996, nr 2, s. 43-44.

Zob. R. McMahon, Augustine's Confessions and Voegelin's Philosophy, „Modern Age” 2006, Vol. 48, nr 1, s. 37-47. „Możemy nawet powiedzieć, że Augustyn był późnoantycznym chrześcijańskim voegelinistą, a Eric Voegelin późnonowożytnym filozoficznym augustynistą" (tamże, s. 46). 
Voegelin przekonuje, iż w obrębie politycznych społeczeństw Zacho$\mathrm{du}$, ostatecznie uformowanych w średniowiecznym modelu Christianitas, istniało od zarania nowe specyficzne napięcie, będące związane z swoistymi cechami, jakie chrześcijaństwo nadało zagadnieniu teologii politycznej ${ }^{30}$. Najogólniej rzecz biorąc, określa ją opozycja między władzą świecką i duchową wywiedziona $\mathrm{z}$ kilku wypowiedzi Jezusa Chrystusa zawartych w Ewangelii ${ }^{31}$, zyskująca na znaczeniu w kulturze politycznej Zachodu szczególnie od czasów chrystianizacji Cesarstwa Rzymskiego w IV wieku, zwieńczonego proklamowaniem chrześcijaństwa religią państwową przez Teodozjusza I Wielkiego. Sposób widzenia tych kwestii oddziaływujący najbardziej przemożnie na późniejszą historię Zachodu, zaproponował na przełomie IV i V wieku św. Augustyn w Państwie Bożym, zajmując krytyczne stanowisko zarazem wobec pogańskiej teologii politycznej Rzymu Marka Terencjusza Warrona $^{32}$ (116-27 przed Chr.), jak i uformowanej w czasach Konstantyna Wielkiego imperialnej (państwowej) teologii politycznej sformułowanej Euzebiusza z Cezarei (ok. 264-ok. 340) . $^{33}$.

Zakreślony przez biskupa z Hippony dualistyczny model civitas terrena i civitas Dei oraz idea władcy jako imperator felix ściśle łączy się, zdaniem Voegelina, z przejściem od chrześcijaństwa eschatologicznego do apokaliptycznego. Jak pisze Voegelin: „odrzucił on wiarę w millenium jako «dziwaczną bajkę» i odważnie obwieścił, że tysiącletnim królestwem będą rządy Chrystusa w jego Kościele w obecnym saeculum i trwać ono będzie do czasu Sądu Ostatecznego nadejścia Królestwa istniejącego już poza sferą ziemską" ${ }^{34}$. Takie rozumienie Kościoła okazało się według Voegelina modelem paradygmatycznym dla epoki średniowiecza, przesądzając o teologiczno-politycznym charakterze całej epoki.

Odnosząc się do koncepcji Warrona, Augustyn dokonał przeformułowania pogańskiej typologii teologii politycznych. Przypomnijmy, że Warron traktując teologię jako „rozumienie i wyjaśnianie tego, co boskie”, ${ }^{\text {, }}$, wyróżnił

${ }_{31}^{30}$ Zob. E. Voegelin, Nowa nauka..., s. 145.

"Oddajcie więc Cezarowi to, co należy do Cezara, a Bogu to, co należy do Boga" (Mt 22, 21); „Królestwo moje nie jest z tego świata” (J 18,36); „Nie miałbyś żadnej władzy nade Mną, gdyby ci jej nie dano z góry” (J 19, 11); „Dana mi jest wszelka władza na niebie i na ziemi” (Mt 28, 18).

${ }^{32}$ Warron nie był jednak autorem tej koncepcji. Zaczerpnął ją od stoika Panajtiosa z Rodos, któremu jednak także trudno przypisać jej autorstwo, ginące w mrokach zapomnienia. Zob. S. Drelich, Panajtios z Rodos, [w:] Encyklopedia polityczna, red. J. Bartyzel, t. 2, Radom 2009, s. 422-425.

33 Zob. Euzebiusz z Cezarei, Życie Konstantyna, przeł. T. Wnętrzak, Kraków 2007.

34 E. Voegelin, Nowa nauka..., s. 104.

35 J. Ratzinger, Prawdziwość chrześcijaństwa, przeł. D. J. Olewiński „Christianitas” 2000, nr 3/4, S. 14 . 
trzy jej rodzaje: teologię mityczną (mystica), polityczną lub obywatelską (politike) oraz fizyczną (physike) albo naturalną (naturalis). „Temu rozparcelowaniu sfery religijno-metafizycznej - komentuje kwestię Jacek Bartyzel chrześcijaństwo przeciwstawiło zdecydowanie nie tylko niezachwianą wiarę w jedynozbawczość religii Chrystusowej jako jedynej religii prawdziwej (religio vera), ale również ideę koniecznej jedności i tożsamości "wiary ludu», «wiary filozofów» i «religii obywatelskiej», co w sposób oczywisty implikuje również podporządkowanie kultu publicznego religio vera" ${ }^{\text {"36 }}$.

Równie krytyczne stanowisko zajął Augustyn w stosunku do teologii państwowej Euzebiusza z Cezarei, realizowanej przez cesarza Justyniana I Wielkiego i ugruntowanej w kulturze bizantyjskiej ${ }^{37}$. Jak zauważa Marek A. Cichocki „warunkiem teologii politycznej w perspektywie Augustyna jest sceptycyzm wobec teologii państwowej i uznanie rozdzielności celów politycznych i celu zbawienia, które dopiero otwiera drogę do postawienia zasadniczego pytania o relację między tym, co transcendentalne, wieczne, jedyne, a wymiarem światowym, skończonym, przemijającym, rozdrobnionym" $"$.

Niemniej jednak problem relacji Kościoła z państwem, czy mówiąc w języku bardziej adekwatnym dla tamtej epoki - stosunek Kościoła do władzy świeckiej, naznaczony był stałym napięciem, związanym w przekonaniu Voegelina z ambiwalentnym stosunkiem chrześcijaństwa do teologii obywatelskiej. Napięcie to obecne było w najistotniejszych koncepcjach i sporach dotyczących tej kwestii począwszy od sformułowanej w V w. doktryny dualistycznej „dwóch mieczy” (papieże: św. Leon I Wieki i św. Gelazy I), przez ideę „wyprowadzenia” (papież Grzegorz II), zasadę monarchiczną Ottonów (X w.), doktryny doby dojrzałego średniowiecza, jak spór o inwestyturę (papież Grzegorz VII Hildebrand), koncepcje państwa Jana z Salisbury, filozofię i teo-

J. Bartyzel, Teologia polityczna, [http://haggard.w.interia.pl/teolpol.html; dostęp: 19.12.2009].

37 „W modelu tym ulegała zatarciu granica miedzy wymiarem politycznym („rzymskością”) a religijnym („,chrześcijańskością”) [...] jedność państwa uosabianego przez autokratora, wykluczała istnienie dwóch wspólnot; państwo było cesarstwem-Kościołem, brak w nim było miejsca dla pośredników między Bogiem i cesarzem, którzy propagowali wiarę opierając się na tytule własnym, bo nadanym im wprost przez Boga" (M. Kuniński, PaństwoKościót, [w:] Stownik społeczny, red. B. Szlachta, Kraków 2004, s. 828-829. Więcej na temat koncepcji imperialnej: B. Szlachta, Pierwszy chrześcijański cesarz? O koncepcjach politycznych Konstantyna Wielkiego i Euzebiusza z Cezarei, „Problemy Społeczne i Ekonomiczne”, vol. 2, Kęty 2005 , s. 57-81. Por. S. Runciman, Teokracja bizantyjska, przeł. M. Radożycka-Paoletti, Katowice 2008.

38 M. A. Cichocki, Wieczny pokój św. Augustyna. Teologia polityczna wobec filozofii politycznej, „Teologia Polityczna" 2003/2004, nr 1, s. 185-193. 
logię polityczną św. Tomasza i koncepcje hierokratyczne ${ }^{39}$, na koncepcjach woluntarystycznych i nominalistycznych (Marsyliusz z Padwy, Wilhelm Ockham) kończąc.

Wystąpienie Hobbesa miało miejsce w zupełnie odmiennej sytuacji, w okresie, kiedy europejska jedność Christianitas należała już zdecydowanie do przeszłości, w czasie formowania się narodowych i suwerennych państw, rozsadzanych przez toczone od XVI wieku wojny religijne; kiedy to, mówiąc za C. S. Lewisem, średniowieczny Model wszechświata nieubłaganie odchodził w przeszłość, wypierany przez nowożytny mechanistyczny racjonalizm myśli naukowej ${ }^{40}$. Życie Hobbesa przypada na niespokojny okres w dziejach jego ojczyzny, czas pierwszej fali radykalnego gnostycyzmu nowożytnego (purytanie) oraz pierwszej nowożytnej rewolucji (angielska wojna domowa) ${ }^{41}$. Wydarzenia te, poza przeobrażeniami natury czysto politycznej, niosły ze sobą także wyzwania o charakterze teoretycznym i intelektualnym, które Hobbes podjął w swoich pismach. Zdaniem Voegelina przemyślał on dogłębnie kwestię nowej teorii ładu politycznego opartego na pokoju i bezpieczeństwie, wplatając w to jednocześnie nowe stanowisko wobec chrześcijaństwa. Próba ta, choć według autora Nowej nauki polityki nieudana i okupiona poważnymi konsekwencjami, zasługuje na uwagę przede wszystkim z tego powodu, że była najlepszą teoretycznie odpowiedzią na gnostyckie zagrożenie destabilizacji ładu przez ruch purytanów niosący ideę przebóstwienia człowieka i społeczeństwa $^{42}$. Po drugie zaś, symbolika zawarta w pracach Hobbesa określa „radykalną immanentyzację współczesnej polityki” ${ }^{43}$.

${ }^{39}$ Na ten temat zob. przede wszystkim doskonałe studium: E. H. Kantorowicz, Dwa ciała króla: studium ze średniowiecznej teologii politycznej, przeł. z ang. M. Michalski, A. Krawiec, Warszawa, 2007, zwłaszcza rozdz. I-III, s. 36-218. Ujęcia panoramiczne tej kwestii: J. Bartyzel, Dwa Miecze. Relacja Kościót-państwo w tradycyjnym nauczaniu $i$ w historii Christianitas, „Zawsze Wierni” 2003, nr 3, s. 20-43; A. Wielomski, Średniowieczna teologia polityczna, „Templum Novum" 2009, nr 8, s. 47-59; W. Wójcik, Doktryny średniowieczne o stosunku dwu władz i udzielaniu pomocy świeckiej, „Prawo Kanoniczne” 1967, z. 1, nr 10, s. 105-141.

Zob. C. S. Lewis, Odwrócony obraz: wprowadzenie do literatury średniowiecznej i renesansowej, przeł. W. Ostrowski, Kraków 2008.

${ }^{41}$ Doskonałą analizę myśli politycznej doby XVII wieku stanowi książka: N. Gładziuk, Druga Babel. Antynomie siedemnastowiecznej angielskiej myśli politycznej, Warszawa 2005.

Zob. E. Voegelin, Nowa nauka..., s. 103 . Voegelin podkreśla, że przebóstwienie nie jest (w przeciwieństwie do teologii imperialnej Euzebiusza z Cezarei) powrotem do epoki kosmologicznej. Jak pisze „przebóstwienie nie oznacza odrodzenia kultury politeistycznej w jego grecko-rzymskim wydaniu. Charakterystyka współczesnych ruchów politycznych jako neopogaństwa jest, mimo pewnej popularności, błędna, ponieważ kosztem powierzchownych podobieństw gubi się to, co specyficzne dla tych ruchów. Współczesne przebóstwienie ma swe źródła w samym chrześcijaństwie i korzysta z tych idei, które jako heretyckie zostały przez Kościół powszechny stłumione" (tamże).

${ }^{43}$ Tamże, s. 167. Na wpływ symboliki Hobbesowskiej zwracał uwagę także, choć w sposób odmienny, C. Schmitt (Lewiatan w teorii...). 
Voegelin twierdzi, że autor Lewiatana wychodzi od dwóch podstawowych założeń. Po pierwsze, stawia on przed sobą zadanie rozpatrzenia imperatywu o konieczności zachowania ładu publicznego w historycznym istnieniu każdej wspólnoty politycznej. Po drugie, zakłada, że największym zagrożeniem dla owej politycznej stasis jest istnienie grup pragnących w imię nowych, nieraz konkurencyjnych prawd zmienić ład polityczny ${ }^{44}$.

Istotą propozycji Hobbesa jest nowa teoria reprezentacji. Cechuje ją przede wszystkim redukcjonistyczne pojmowanie teologii obywatelskiej. Prawda publiczna - przekonuje Voegelin - ograniczona jest wyłącznie do kwestii egzystencjalnego przetrwania wspólnoty politycznej. „Poza prawem pokoju i zgody - pisze w Lewiatanie Hobbes - nie istnieje żadna prawda publiczna" ${ }^{45}$, natomiast wszystko, co zaburza pokój, jest fałszem.

O zredukowanej do takiej postaci prawdzie publicznej decyduje suweren - Hobbesowski Lewiatan, w którego prerogatywach skumulowana jest cała domena teologii obywatelskiej. Jest to zatem odejście od modelu średniowiecznego, będące przełamaniem zakorzenionego przez św. Augustyna sceptycyzmu wobec teologii obywatelskiej, jak i zwrócenie uwagi, że owa kwestia odgrywa pierwszorzędną rolę w kondycji wspólnot politycznych nowożytnych państw. Co charakterystyczne i nowe względem epok Christianitas, reprezentacja egzystencjalna i transcendentalna spotykają się ${ }^{46}$. Oznacza to, że zanegowaniu ulega średniowieczna opozycja władzy duchowej i świeckiej, jednak za cenę radykalnej deformacji klasycznej i chrześcijańskiej antropologii, a tym samym całościowej wizji polityki. „Był to o tyle doskonały pomysł - podsumowuje tę kwestię Voegelin - iż cały ciężar spadł na istnienie, tak głęboko przez gnostyków lekceważone. Z kolei praktyczna wartość tej idei wspierała się na założeniu, że prawda transcendentalna, którą ludzie pragnęli w swoich społeczeństwach reprezentować, po tym jak przeszli przez doświadczenie filozofii i chrześcijaństwa, została odrzucona [...] Hobbes przeciwstawił się gnostyckiej immanentyzacji eschatonu zagrażającej istnieniu, dokonując radykalnej immanentyzacji egzystencji, odrzucając w ogóle sam eschaton" ${ }^{, 7}$.

Voegelin dokonując oceny dorobku Hobbesa, zwraca uwagę na konsekwencje tej teorii, które można sprowadzić do czterech generalnych kwestii: 1) Odwrócenie stosunku theologia supranaturalis i theologia civilis polegające na uczynieniu z chrześcijaństwa teologii publicznej. Jest to w istocie ujęcie do-

Zob. tamże, s. 140.

Tamże.

${ }^{46}$ Temat reprezentacji jest kluczowym pojęciem $w$ teologii politycznej Voegelina. Zob. E. Voegelin, Nowa nauka..., s. 37-76.

Tamże, s. 162. 
kładnie odwrotne względem tego, jakie znajdujemy u Ojców Kościoła, którzy, traktując chrześcijaństwo jako prawdę duszy, ignorowali kwestię prawdy publicznej; 2) Negacja napięcia między prawdą duszy a prawdą społeczeństwa poprzez eliminację prawdy duszy. Ignorując prawdę duszy, teoria ta koncentruje się w pełni na prawdzie publicznej. Wielkie osiągnięcie Hobbesa - przekonuje Voegelin - polega na odkryciu, że nie można zachować ładu politycznego bez istnienia teologii obywatelskiej ${ }^{48}$. Czyni to jednak kosztem ograniczenia horyzontu antropologicznego; 3) Uproszczenie polityki objawiające się odrzuceniem prawdy antropologicznej i soteriologicznej. Polityka okazuje się dziedziną, której nie dotyczy doświadczenie transcendencji; 4) Nowa idea wychowania jako środek utrzymywania ładu politycznego w sposób pokojowy i dobrowolny. Celem nowej paidei jest sytuacja, w której podporządkowanie publicznemu reprezentantowi będzie rozumiane przez poddanych jako wyraz wiecznego prawa ${ }^{49}$, gdyż jak zaznacza Voegelin: „na należytym kierowaniu opinią polega należyte kierowanie działaniami ludzi, izby one prowadziły do pokoju i zgody. I chociaż tam, gdzie chodzi o doktryny, należy mieć na względzie tylko prawdę, to przecież nie jest to niezgodne $\mathrm{z}$ regulowaniem doktryn ze względu na interes pokoju. Doktryna naruszająca pokój nie może być prawdziwa, tak samo jak pokój i zgoda nie mogą być sprzeczne z prawem natury" ${ }^{, 50}$.

Jak twierdziliśmy wcześniej, według Voegelina chrześcijański stosunek do teologii politycznej był obarczony swoistym sceptycyzmem odnośnie do ładu publicznego, który narażał wspólnoty polityczne na poważne zagrożenie rozpadu. Słabości tego typu myślenia wyszły na powierzchnię przy okazji pojawienia się purytańskiego gnostycyzmu. Choć teoria Hobbesa miała być odpowiedzią na niedostatki średniowiecznego dziedzictwa, jak i lekarstwem na gnostyckie zagrożenie, podziela jednak z gnostykami dwa generalne założenia. Po pierwsze, podobnie jak purytanie, Hobbes jest przekonany, że wobrębie społeczeństw możliwe jest usunięcie napięcia teologicznopolitycznego. Po drugie, autor Nowej nauki polityki zwraca uwagę, że Hobbes, choć tłumi duszę rozumianą jako zmysł transcendencji, jest też przekonany, że usuwa ją trwale i skutecznie z egzystencji człowieka ${ }^{51}$.

Tamże, s. 145.

Zob. tamże, s. 146.

T. Hobbes, Lewiatan, II, 18, s. 265.

Zob. E. Voegelin, Nowa nauka..., s. 151. Por. E. Voegelin, Namiastka religii, przeł. J. Światek, „Człowiek w Kulturze" 2005, nr 17, s. 271-290 (fragment pracy: E. Voegelin, Wissenschaft, Politik, und Gnosis, Münich 1959), gdzie Voegelin znacznie bardziej zdecydowanie umieszcza Hobbesa w tradycji gnostyckiej. 
Wskazując na podobieństwa z gnostycyzmem, Voegelin wyraźnie akcentuje niezwykle istotną w tym odczytaniu myśli Hobbesa uwagę wskazującą, że zasadniczo różni się ona od podejścia gnostyckiego. $\mathrm{O}$ ile w teologii obywatelskiej proponowanej przez gnostyków ciężar położony jest na prawdę, o tyle u Hobbesa ciężar teorii pada na samo istnienie, zaś prawda - za sprawą skrajnego redukcjonizmu - jest właściwie ignorowana. Gnostycka wizja polityki wyrasta wprost z chrześcijaństwa, jest jego zimmanentyzowaną odmianą. Propozycja Hobbesa stanowi natomiast koncepcję radykalnie odmienną od dotychczasowej tradycji, opiera się na zupełnie nowym obrazie człowieka.

\section{Amor sui}

W zaproponowanym przez Hobbesa ujęciu człowieka, dominującą cechę stanowi nigdy niezaspokojone pragnienie mocy (libido dominandi). W Lewiatanie czytamy: „Nie ma bowiem takiego finis ultimus (ostatecznego celu) ani sumum bonum (najwyższego dobra), o jakich się mówi w księgach starych filozofów moralnych. I nie może już żyć człowiek, u którego zanikły pożądania, podobnie jak człowiek, u którego zatrzymał się bieg doznań zmysłowych i wyobrażeń" ${ }^{52}$. Zdaniem Voegelina Hobbes dostrzegł u purytanów niszczący wspólnotę polityczną wpływ libido dominandi, jednak nie odrzucił tego elementu, wskazując, że stanowi on trwałą i podstawową cechę natury człowie$\mathrm{ka}^{53}$. Konstruując swoją teorię, postanowił natomiast wykluczyć, stanowiące fundament klasycznej i chrześcijańskiej etyki - wspólne dobro (sumum bonum). „Jeśli ludzie - pisze - nie mogą skłonić się poprzez wzajemną miłość do boskiego najwyższego dobra, aby pokojowo żyć, to muszą być przymuszeni do porządku w społeczeństwie poprzez lęk przed sumum malum śmierci" ${ }^{54}$.

Przyjęcie takich założeń wiąże się z nową perspektywą antropologiczną. Rozpatrując ją w kontekście tradycji kultury zachodniej, oznacza ona odejście od platońskiej psychologii orientacji i zwrot ku nowej, postulowanej przez Hobbesa psychologii motywacji ${ }^{55}$. Innymi słowy, jest to odejście od rozumienia człowieka, którego egzystencja jest określona w odniesieniu do transcendentnego Boga, oznacza zredukowanie dwuelementowej koncepcji człowieka, w którego centrum znajdują się dwa wolicjonalne centra: amor Dei i amor sui do takiej wizji, w której istnieje wyłącznie amor sui. Oznacza to nie

\footnotetext{
T. Hobbes, Lewiatan, I, 11, s. 177-178.

„Tak więc na pierwszym miejscu stawiam jako ogólną skłonność wszystkich ludzi stałe i nieznające spoczynku pragnienie coraz to większej mocy, które ustaje ze śmiercią" (tamże, I, 11, s. 178).

E. Voegelin, Namiastka religii..., s. 283.

Zob. tenże, Nowa nauka..., s. 167.
} 
tyle przejście od teocentrycznej ku antropocentrycznej wizji człowieka, lecz całościową zmianę oglądu spraw ludzkich ${ }^{56}$. Jak ironizuje Voegelin: ,jest to pragnienie zrozumiałe w człowieku, który chciał swego pokoju; wszystko przecież będzie prostsze bez filozofii i chrześcijaństwa" ${ }^{{ }^{57}}$. Wspomniany wcześniej redukcjonizm dotyczący rozumienia polityki, spraw publicznych, jest powiązany ściśle $\mathrm{z}$ jego wariantem na planie antropologicznym. Teoria Lewiatana poskramiająca owe dzieci pychy „wymaga wielkich kosztów”, Hobbes nie traktował namiętności i ich dominacji w życiu indywidualnej osoby, jak i ciała politycznego jako wyrazu choroby, „zniszczenia życia ducha”, lecz uznał - zdaniem Voegelina - „że życie duchowe jest skrajnym wyrazem tej namiętności, [...] że życie namiętnością stanowi o naturze człowieka; tedy życie duchowe przedstawiało mu się jako skrajna postać superbia" ${ }^{, 59}$.

Voegelin wpisuje ten sposób ujęcia problemu duszy przez Hobbesa w tradycję nowożytnej psychologii, obok takich nurtów jak francuska szkoła moralistów i powieściopisarzy, angielska psychologia przyjemności i bólu, asocjacjonizm, niemiecka psychologia nieświadomego romantyków i Nietzchego. „Psychologia nowożytna - stwierdza - jest psychologią niepełną. Odnosi się bowiem tylko do pewnego pneumopatologicznego typu człowieka" ${ }^{\text {"0 }}$.

Podsumowując prowadzone $\mathrm{w}$ tym miejscu rozważania, można stwierdzić, że Voegelin, czytając Hobbesa, zwraca uwagę na trzy zasadnicze kwestie, które charakteryzują jego filozofię polityczną: 1) nowa teoria reprezentacji, sytuująca w centrum teologię obywatelską; 2) przeniesienie akcentu z wymiaru eschatologicznego na wymiar egzystencjalny w pojmowaniu polityki; 3) zaproponowanie nowej psychologii i antropologii jako drogi, dzięki której dwa poprzednie kroki stają się możliwe.

Przeprowadzona tu analiza skłania także do przyjęcia wniosku o charakterze generalnym, mówiącym, że w interpretacji Voegelina Hobbes jawi się jako wielki teoretyk ateizmu politycznego. Jego teoria, mająca być lekarstwem na rozgorączkowany eschatologiczny immanentyzm gnostyckich purytanów, jest radykalną redukcją wypracowaną przez klasyczną i chrześcijańską wizję człowieka i życia we wspólnocie politycznej.

56 Por. z diagnozą filozofii politycznej sformułowaną przez Leo Straussa, który wskazuje, że refleksję nowożytną refleksję $\mathrm{w}$ tym zakresie charakteryzuje radykalne obniżenie standardów (L. Strauss, Czym jest filozofia polityki?, [w:] tegoż, Sokratejskie pytania, przeł. P. Maciejko, Warszawa 1998, s. 91-106).

E. Voegelin, Nowa nauka..., s. 167.

Tamże, s. 163.

Tamże.

Tamże, s. 167. 


\section{Między gnostycyzmem a chrześcijaństwem}

Zastanawiać może fakt, że u tak zdecydowanego krytyka nowożytności, jakim był bez wątpienia Voegelin, można znaleźć wiele słów uznania i podziwu dla Hobbesa. We fragmentach poświęconych Hobbesowi natrafiamy na szereg potwierdzających to sformułowań. Autor Lewiatana jest charakteryzowany jako „myśliciel, który stanął na wysokości zadania”, „wielki myśliciel”, ,jeden z najwybitniejszych psychologów wszechczasów”, „wielki teolog partykularnej eklezji”. Jego myśl „dociera wprost do istoty rzeczy”, cechuje ją ,imponująca spójność”, stanowi ona „doskonały pomysł”, „wielkie i trwałe osiągnięcie”, ,wielkie odkrycie”. Voegelin umieszcza Hobbesa w szeregu najważniejszych myślicieli Zachodu, na gruncie teologii politycznej porównując go z św. Pawłem, a w dziedzinie psychologii z Fryderykiem Nietzschem ${ }^{61}$.

Jednak nie tylko oczywiste różnice filozoficzne, jakie dzielą obu myśliciel, czynią te konstatacje intrygującymi, lecz także fakt, że z punktu widzenia Voegelina teoria Hobbesa, mająca być pewnego rodzaju trzecią drogą między radykalnym gnostycyzmem a chrześcijaństwem, okazała się próbą nieudaną ${ }^{62}$. Myśl Hobbesa, mimo swej imponującej konstrukcji teoretycznej i retorycznej siły oddziaływania, nie osiągnęła zakładanego celu, czyli powstrzymania rozwoju gnostycyzmu cechującego się eschatologicznym pojmowaniem polityki w jej zimanentyzowanej odmianie. W kolejnych stuleciach dzieje Zachodu pomknęły szybko w kierunku tego, co Voegelin określa mianem „nowożytności bez ograniczeń”, czego najbardziej oczywistą egzemplifikacją były w dwudziestym stuleciu nazizm i komunizm. Kraje zaś, które w opinii Voegelina miały uchodzić w dwudziestym wieku za politycznie najzdrowsze, jak USA czy Wielka Brytania, posiadały „utrwaloną warstwę cywilizacyjnej tradycji" w większym stopniu, dzięki przejściu gnostyckiej choroby stosunkowo wcześnie, zachowując przy życiu wiele z chrześcijańskiej cywilizacji, aniżeli za sprawą wpływu autora Lewiatana ${ }^{63}$. Nie wydaje się zatem, by Voegelin przydawał w zmaganiach z gnostycyzmem teorii repre-

Zob. E. Voegelin, Nowa nauka..., s. 140, 145, 162; tenże, The Political Religions..., s. 53; tenże, The New Order and Last..., s. 59-62.

62 Zob. zakończenie Nowej nauki polityki, s. 169-170. Por. słowa Hobbesa, który pisze w dedykacji do Lewiatana: „Trudno jest bowiem przejść drogą obsadzoną z jednej strony przez tych, którzy walczą o zbyt wielką wolność, a z drugiej przez tych, którzy walczą o zbyt wielką władzę, nie otrzymawszy ran z obu stron" (T. Hobbes, Lewiatan..., s. 79). 
zentacji Hobbesa większe znaczenie, wskazując raczej na to, że pogłębiła ona zjawisko immanentyzacji polityki nowożytnej.

Tym samym można powiedzieć, że Voegelin nie podziwiał autora Lewiatana za skuteczną walkę z gnostyckim zagrożeniem. Jak już wcześniej wspominaliśmy, dostrzegał zresztą w myśli Hobbesa „zapowiedź totalitaryzmu", choć zdecydowanie odżegnywał się od uznania jego teorii za wprost totalitarną, krytykował także interpretacje uznające go za rzecznika absolutyzmu czy rojalizmu ${ }^{64}$. Nie był też w jego ocenie Hobbes rzecznikiem tendencji indywidualistycznych bądź kolektywistycznych, lecz „wielkim psychologiem", myślicielem, który dał swoim dziełem doskonały portret choroby ducha (pneumopatologii) człowieka nowożytnego. Tym samym myślicielem, który przeniknął dogłębnie sens nowożytnego rozumienia polityki, a także wyartykułował ogromne znaczenie kwestii, która w średniowieczu była w dużym stopniu niedoceniona, a mianowicie, że nie sposób zachować stabilnego ładu politycznego bez teoretycznie ugruntowanych podstaw teologii obywatelskiej.

Porażka Hobbesa w pojedynku z gnostycyzmem - zdaje się sugerować autor Nowej nauki polityki - jest także pouczająca, mówi bowiem, że gnostyckiego redukcjonizmu purytanów głoszących immanentyzację eschatonu „nie można zastąpić jego inną odmianą - «immanentyzacją egzystencji»”. Konieczna jest taka perspektywa polityki, która jest w stanie „zinterpretować naturę człowieka z perspektywy pełnego zróżnicowania ludzkiej duszy danej w doświadczeniu transcendencji”; teologia polityczna uwzględniająca zarówno prawdę antropologiczną, jak i soteriologiczną. Wyznaczają one nieusuwalne napięcie rządzące ludzką egzystencją, w tym także dziedziną polityki. Voegelin, podziwiając zatem Hobbesa w jego staraniach wyciszenia ludzkiej hybris, zwraca się otwarcie ku tradycji śródziemnomorskiej, wskazując na Gościa z Aten ${ }^{65}$ jako przewodnika w zmaganiach człowieka z problemem ładu. Odrzucając pośrednią drogę Hobbesa, sam kroczy gdzieś pomiędzy brzemiennym dla nowożytności chrześcijaństwem a klasyczną kulturą grecką.

M I C H A E J. C Z A R N E K I

${ }_{64}$ Zob. E. Voegelin, Nowa nauka..., s. 168; tenże, The Political Religions, s. 55; tenże, The New Order..., s. 71-72.

${ }^{65}$ Zob. interpretację Platońskich Praw (E. Voegelin, Platon, przeł. A. Legutko-Dybowska, Warszawa 2009, s. 331-409). 


\section{Abstract}

Hobbes's political philosophy was analysed by several significant political philosophers of $20^{\text {th }}$ century, like Carl Schmitt, Leo Strauss, Michael Oakeshott. In mid$20^{\text {th }}$ century, they wrote very influential books and essays about Hobbes. There can be a strong trend of analyses concerning this theme distinguished in post-war political philosophy, including authors sympathising with marxism (C. B. Macpherson), liberalism (D. Gauthier), conservatism (M. Ayuso Torres) or republicanism (Q. Skinner).

Nevertheless, in modern political philosophy one may point at such important thinkers as F. L. Neumann or B. de Jouvenel, who didn't write any book on Hobbes, but their works were strongly inspired by Hobbes' philosophy. To this group belongs also Eric Voegelin (1901-1985), well known for his thesis about Gnostic character of modernity. Voegelin emphasises importance of Hobbes' thought while emergence of modern period in Western civilization.

In the essay, the author attempts to reconstruct Voegelin's interpretation of Hobbes' political philosophy. According to the author, Voegelin emphasises two principal issues in Hobbes' works: new anthropology and political theology. In the field of new anthropology Voegelin points the fact that Hobbes breaks with Augustinian psychology of orientation (amor Dei and amor sui as two cores of soul) in favour of psychology of motivation (only amor sui). In the context of political theology, Voegelin emphasises the remark of Hobbes, stating that it maintaining public order without civil theology is, in fact, impossible.

In Voegelin's interpretation, Hobbes is an author who tries to present a theory situated between Christianity and radical Gnosticism (puritans). But from Voegelin's perspective, his philosophy may be defeated, as in principal aspects Hobbes is under influence of Gnostic way of thinking. 